\title{
Simulation of 1D surface and 2D subsurface water flow and nitrate transport in alternate and conventional furrow fertigation
}

\author{
Hamed Ebrahimian ${ }^{1 *}$, Abdolmajid Liaghat ${ }^{1}$, Masoud Parsinejad ${ }^{1}$, Enrique Playán², \\ Fariborz Abbasi $^{3}$ and Maryam Navabian ${ }^{4}$
}

${ }^{1}$ Department of Irrigation and Reclamation Eng., College of Agriculture and Natural Resources, University of Tehran, P. O. Box 4111, Karaj 31587-77871, Iran.

${ }^{2}$ Soil and Water Department, Estación Experimental de Aula Dei, EEAD-CSIC. P. O. Box 13034. 50080 Zaragoza, Spain. Email: enrique.playan@,csic.es

${ }^{3}$ Agricultural Engineering Research Institute (AERI), Karaj, Iran

${ }^{4}$ Department of Water Eng., Faculty of Agriculture, University of Guilan, Rasht, Iran.

* Corresponding author,

Email: ebrahimian@,ut.ac.ir

Telefax: +982612241119 


\section{Simulation of 1D surface and 2D subsurface water flow and nitrate transport in alternate and conventional furrow fertigation}

\section{$\underline{\text { Abstract }}$}

Increasing water and fertilizer productivity stands as a relevant challenge for sustainable agriculture. Alternate furrow irrigation and surface fertigation have long been identified as water and fertilizer conserving techniques in agricultural lands. The objective of this study was to simulate water flow and fertilizer transport in the soil surface and in the soil profile for variable and fixed alternate furrow fertigation and for conventional furrow fertigation. An experimental data set was used to calibrate and validate two simulation models: a $1 \mathrm{D}$ surface fertigation model and the $2 \mathrm{D}$ subsurface water and solute transfer model HYDRUS-2D. Both models were combined to simulate the fertigation process in furrow irrigation. The surface fertigation model could successfully simulate runoff discharge and nitrate concentration for all irrigation treatments. Six soil hydraulic and solute transport parameters were inversely estimated using the Levenberg-Marquardt optimization technique. The outcome of this process calibrated HYDRUS-2D to the observed field data. HYDRUS-2D was run in validation mode, simulating water content and nitrate concentration in the soil profiles of the wet furrows, ridges and dry furrows at the upstream, middle and downstream parts of the experimental field. This model produced adequate agreement between measured and predicted soil water content and nitrate concentration. The combined model stands as a valuable tool to better design and manage fertigation in alternate and conventional furrow irrigation.

Key words: alternate furrow irrigation, fertigation, nitrate, simulation, soil water 


\section{Introduction}

Alternate furrow irrigation has been applied in arid and semi-arid regions to conserve water and to increase water productivity (Kang et al. 2000; Horst et al. 2007; Thind et al. 2010; Slatni et al. 2011). In open watersheds, water conservation may lead to the intensification of irrigated agriculture, with the irrigation of additional land or the cultivation of more water demanding crops (Seckler et al. 2003). The basic principle of alternate furrow irrigation is to apply water to one of two continuous furrows. The application of this technique permits to irrigate only half of the furrows in a set. This does not necessarily reduce water use to one half, since lateral infiltration may increase in the irrigated (wet) furrows, as water expands to the non-irrigated (dry) neighboring furrows. Two management strategies have been reported for alternate furrow irrigation: 1) variable alternate furrow irrigation (AFI), in which the irrigated furrow changes from one irrigation to the next; and 2) fixed alternate furrow irrigation (FFI), in which the irrigated furrow is the same throughout the irrigation season (Kang et al. 2000).

Fertilizer and pesticide losses in agricultural fields have often been reported to result in the pollution of water resources, groundwater or rivers (Ongley 1996). For instance, in Iran the consumption of chemical fertilizers per unit cultivated area increased from $312 \mathrm{~kg} \mathrm{ha}^{-1}$ in 2000 to $386 \mathrm{~kg} \mathrm{ha}^{-1}$ in 2007 (Sepaskhah 2010). Increasing crop yield should not compromise the sustainable use of natural resources, such as soil and water. While surface fertigation has often resulted in poor fertilizer distribution uniformity and relevant fertilizer runoff losses (Playán and Faci 1997), when fertigation parameters are optimized its performance can be very satisfactory

(Adamsen et al. 2005; Perea et al. 2010). From the agronomic point of view, 
fertigation always represents an advantage when crop height or crop land coverage does not permit to apply fertilizers using tractors and broadcasting equipments.

Abundant research has been performed in the last decades to simulate surface water flow and solute transport under surface fertigation (Abbasi et al. 2003c; Boldt et al. 1994; Burguete et al. 2009; Izadi et al. 1996; Perea et al. 2010; Playán and Faci 1997; Sabillón and Merkley 2004). These authors reported that simulation could be effectively applied to improve surface fertigation design and management, reducing water and fertilizer losses. Playán and Faci (1997) stated that a short duration of the fertilizer injection often resulted in low fertilizer distribution uniformity in border fertigation. However, Sabillón and Merkley (2004) advocated relatively short injection times and relatively high injection rates in furrow fertigation. Abbasi et al. (2003c) conducted a blocked-end furrow fertigation experiment and simulated overland water flow and solute (bromide) transport. These authors reported that high solute uniformity was obtained when the solute was applied during the entire irrigation event or during the second half of the irrigation event. Burguete et al. (2009) presented a fertigation model for furrow irrigation. Model simulations succeeded in predicting fertilizer concentration in irrigation water at different times and distances along the furrow for different fertilizer application strategies.

Numerical models are being increasingly used for simulating water and solute movement in the soil. Benjamin et al. (1994) simulated solute transport in alternate and conventional furrow irrigation under broadcast fertilization using the SWMS-2D model (Šimůnek et al. 1994). Their results suggested that the fertilizer applied on the non-irrigated (dry) furrows (alternate furrow irrigation) in a loamy sand soil may not be available for plant uptake. This conclusion derived from the fact that the upper layer of the dry furrow did not increase its water content during the irrigation event. 
Mailhol et al. (2001) evaluated the effect of the placement of the nitrogen fertilizer within the furrow on nitrogen soil profile and leaching. A fraction of the applied nitrogen was stored in the upper part of the top ridge and reduced the risks of nitrate leaching. They also stated that a 2D water- and solute transport model such as HYDRUS-2D (Šimůnek et al. 1999b) could simulate nitrogen distribution under a furrow cross-section better than a simplified 1D water- and solute transport model. Abbasi et al. (2004) calibrated and validated HYDRUS-2D for blocked-end furrow irrigation with the objective of simulating water content and solute concentration. Satisfactory agreement was reported by these authors between measured and predicted soil water. Solute concentration along the furrow cross-sections was not predicted with the same accuracy as with soil water. Crevoisier et al. (2008) calibrated and applied HYDRUS-2D for conventional furrow irrigation (CFI) and fixed alternate furrow irrigation (FFI) under broadcasting fertilization in the dry furrows. These authors reported that model performance (evaluated in terms of soil matric potential and nitrate concentration) was satisfactorily accurate. Simulations for FFI were less accurate than for CFI. Wöhling and Schmitz (2007) presented a seasonal furrow irrigation model by coupling a 1D zero-inertia surface flow model, HYDRUS-2D and a crop growth model. The coupled model was evaluated using experimental data. The advance and recession times, soil moisture and crop yield were adequately simulated (Wöhling and Mailhol, 2007). This study demonstrated the high potential of the coupled model to improve irrigation design and management.

The combination of overland and soil water and solute flow modeling has the potential to address the optimization of the complex processes involved in alternate furrow fertigation. Progress in numerical models has led to robust overland and underground models able of coping with furrow fertigation in water and in the soil. 
Combining both types of models poses a relevant challenge in terms of data transfer and - particularly - in terms of calibration-validation. Such a combined model would be particularly useful in the design of furrow fertigation under performance constraints in terms of irrigation (water and fertilizer runoff and uniformity) and in terms of effective storage of water and fertilizer in the soil. An additional problem, the chemical transformation of the fertilizer in the soil, could be addressed via simulation and make part of the calibration-validation effort. The originality of the present study lies in testing this modeling approach in two different alternate furrow fertigation configurations: AFI and FFI.

The objectives of this paper were: 1) To combine furrow irrigation and soil models oriented to water and fertilizer transport, balance and chemical transformation; and 2) To simulate fertigation for two alternate furrow irrigation strategies (AFI and FFI), as well as for conventional furrow irrigation (CFI). The 1D surface fertigation model by Abbasi et al. (2003c) and the water and solute soil transport model HYDRUS-2D (Šimůnek et al. 1999b), were used in this paper for simulating water flow and fertilizer transport in the furrow irrigation water and in the soil subsurface, respectively. The calibration and validation of the models was conducted using measured data collected in a field experiment. 


\section{Material and methods}

\section{Field experiment}

A field experiment was designed to evaluate alternate furrow fertigation and to produce a data set for modeling applications. The experiment was presented by Ebrahimian et al. (201X), focusing on fertigation performance and on the evaluation of soil water and fertilizer flow. In this paper, the experiment will be briefly presented since it constitutes the basis for model calibration and validation.

The experiment was performed at the experimental station of the College of Agriculture and Natural Resources, University of Tehran, Karaj, Iran. The region is characterized by a Mediterranean continental climate, with an average annual rainfall of $265 \mathrm{~mm}$ and an average annual temperature of $16{ }^{\circ} \mathrm{C}$. Physical soil properties for the upstream, middle and downstream parts of the experimental field are presented in Table 1. Soil depth was limited to $0.60 \mathrm{~m}$, due to the presence of a gravel layer. Maize (Zea mays, single cross 704, Iranian Seed and Plant Improvement Institute) was cultivated for one growing season (June 10 to September 15, 2010). Pre-sowing fertilizer application was limited to $10 \%$ of the nitrogen fertilizer requirements (200 kg N ha ${ }^{-1}$ ), which was applied the day before sowing using a mechanical broadcaster. Three nitrogen dressings (each of them amounting to $30 \%$ of the fertilizer requirements) were applied at the vegetative (seven leaves, in July 7), flowering (August 9) and grain filling (August 30) growth stages using surface fertigation. Nitrogen fertilizer was applied in the form of granulated ammonium nitrate.

Three free draining furrow irrigation treatments: conventional, alternate, and fixed furrow irrigation (CFI, AFI and FFI, respectively) were established at the experimental field. The experiment used 14 furrows: 6 furrows for AFI (three wet and 
three dry), 5 furrows for FFI (three wet and two dry), and 3 furrows for CFI (three wet). In each irrigation treatment, only the central wet furrow was monitored. The other two wet furrows acted as guards. Figure 1a presents the experimental layout of the FFI treatment. The field was arranged so that the three treatments were adjacent to each other. The furrow spacing was $0.75 \mathrm{~m}$, the furrow length was $86 \mathrm{~m}$, and the longitudinal slope was 0.0093 . Water and fertilizer amounts were the same in all irrigated furrows in the three irrigation treatments. As a consequence, water and fertilizer application per unit area was double in CFI than in AFI or FFI.

Irrigation water was pumped from a canal to a reservoir. A weir was installed at a lateral reservoir outlet to provide constant head inside the reservoir and consequently constant discharge at the three furrow irrigation outlets. Water was individually delivered to each experimental furrow (main and guard furrows) using polyethylene pipes (25 $\mathrm{mm}$ in diameter). Furrow inflow and outflow (runoff) discharges were measured using WSC flumes installed at the inlet and outlet of each experimental furrow. Stations were marked every $10 \mathrm{~m}$ at the experimental furrows in order to characterize irrigation advance and recession times.

The fertilizer solution was individually applied at the upstream end of each experimental furrow using small containers, each having a capacity of $8 \mathrm{~L}$. Containers were equipped with regulation valves and floaters in order to maintain pre-set injection rates. The fertilizer solution was prepared in advance in a $220 \mathrm{~L}$ barrel. The containers were calibrated for the desired injection rate before each experiment. Each container was connected to the barrel using flexible pipes with a diameter of $12.5 \mathrm{~mm}$ (Fig. 1b).

Auger soil samples were collected at dry (non-irrigated) and wet (irrigated) furrow beds and ridges in three soil layers (0.0-0.2, 0.2-0.4 and 0.4-0.6 m). Samples were 
obtained from the upstream, middle and downstream sections of the field, to monitor the evolution of soil water content and nitrate concentration during the first and second fertigation events. All auger holes were refilled to avoid disturbances in the soil water profile. Plant height was 0.3 and $1.0 \mathrm{~m}$ at the first and second fertigation events, respectively. The days for soil sampling were July 6, 8, and 13 for the first fertigation event (dated July 7) and August 8, 11 and 15 for the second fertigation event (dated August 9). A total of 864 soil samples were collected. Soil water content was determined by oven drying at $105^{\circ} \mathrm{C}$. Soil nitrate was determined in 5:1 soil extracts (water:soil) using a spectrophotometer (6705 UV/Vis, Jenway).

Crop evapotranspiration was estimated using the CROPWAT software (Smith 1992). The process involved determining reference evapotranspiration using meteorological data form a station located in the experimental station and using crop information to estimate the value of the crop coefficient. Daily crop evapotranspiration for the first and second fertigation events was estimated as 4.8 and $6.6 \mathrm{~mm} \mathrm{day}^{-1}$, respectively. The irrigation interval was 7 days. This interval was maintained throughout the irrigation season. During the first fertigation event, the discharge was $0.262 \mathrm{~L} \mathrm{~s}^{-1}$, and the time of cutoff was $240 \mathrm{~min}$. In this event the fertilizer solution was injected during $150 \mathrm{~min}$ after the time of advance (about $50 \mathrm{~min}$, depending on the particular furrow). During the second fertigation event, the discharge was $0.388 \mathrm{~L} \mathrm{~s}^{-1}$, and the time of cutoff was $360 \mathrm{~min}$. In this event the fertilizer solution was injected during the first half of the irrigation time. The average nitrate concentration at the fertilizer solution tank was $200 \mathrm{~kg} \mathrm{~m}^{-3}$ in both events. The nitrate concentration of the irrigation water from the reservoir (before fertilizer injection) was 36.6 and $41.2 \mathrm{mg} \mathrm{L}^{-1}$ for the first and second fertigation events, respectively.

\section{Overland surface fertigation model}


A combined overland water flow and solute transport model (Abbasi et al. 2003c) was used for the simulation of the overland processes involved in furrow fertigation. The governing equations for water flow were solved in the form of a zero-inertia approach of the Saint-Venant's equations [Eqs. 1 and 2] using a control volume of moving cells linearized by means of a Newton-Raphson algorithm. This model can simulate all phases of both border and furrow irrigation systems using free draining or blockedend conditions (Abbasi et al. 2003a). The governing equations can be written as:

$$
\begin{aligned}
& \frac{\partial Q}{\partial x}+\frac{\partial A}{\partial t}+\frac{\partial z}{\partial t}=0 \\
& \frac{\partial y}{\partial x}=S_{0}-S_{f}
\end{aligned}
$$

where $Q$ is flow rate $\left[\mathrm{L}^{3} \mathrm{~T}^{-1}\right] ; A$ is flow area $\left[\mathrm{L}^{2}\right] ; z$ is infiltrated water volume per unit length of the field $\left[\mathrm{L}^{3} \mathrm{~L}^{-1}\right] ; y$ is flow depth [L]; $S_{0}$ is field slope (dimensionless); $S_{f}$ is hydraulic resistance slope (dimensionless); and $t$ and $x$ are time [T] and space [L], respectively.

Infiltration was characterized using the Kostiakov-Lewis equation:

$$
z=k \tau^{a}+f_{0} \tau
$$

where $\tau$ is infiltration opportunity time [T], and $k\left[\mathrm{~L}^{2} \mathrm{~T}^{-\mathrm{a}}\right], a$ (dimensionless) and $f_{0}$ $\left[\mathrm{L}^{2} \mathrm{~T}^{-1}\right]$ are infiltration parameters.

Solute transport was modeled using the 1D cross-sectional average dispersion equation (Cunge et al. 1980):

$$
\frac{\partial(A C)}{\partial t}+\frac{\partial(A U C)}{\partial x}=\frac{\partial}{\partial x}\left(A K_{x} \frac{\partial C}{\partial x}\right)
$$


where $C$ and $U$ are cross-sectional average concentration $\left[\mathrm{M} \mathrm{L}^{-3}\right]$ and velocity $\left[\mathrm{L} \mathrm{T}^{-1}\right]$, respectively; and $K_{x}$ is the longitudinal dispersion coefficient $\left[\mathrm{L}^{2} \mathrm{~T}^{-1}\right]$. Coefficient $K_{x}$ incorporates both dispersion due to differential advection and turbulent diffusion (Cunge et al. 1980). The dispersion coefficient for transport in overland flow can be described as:

$$
K_{x}=D_{x} U_{x}+D_{d}
$$

where $D_{x}$ is longitudinal dispersivity [L]; $D_{d}$ is molecular diffusion in free water $\left[\mathrm{L}^{2} \mathrm{~T}^{-1}\right]$, and $U_{x}$ is overland flow velocity at location $\mathrm{x}\left[\mathrm{L} \mathrm{T}^{-1}\right]$. The one-dimensional transport equation was solved using a Crank-Nicholson finite difference scheme.

The maximum time and space steps for the fertigation model were calculated using the Peclet $(\mathrm{Pe})$ and Courant $(\mathrm{Cr})$ numbers to eliminate numerical oscillations. Maximum values of these numbers were set to 5 and 1, respectively, as recommended in Abbasi et al. (2003c). The upstream boundary condition was the irrigation discharge for water and the applied nitrate concentration for fertilizer. The downstream boundary condition was uniform runoff flow for water and zero concentration gradient for fertilizer. Zero flow depth, velocity and fertilizer concentration were used as initial conditions along the entire furrow.

A summary of input data for all irrigation treatments and for both fertigation events is presented in Table 2. The Manning's $n$ was assumed to be 0.04 in all cases since the irrigated soil was not covered by vegetation (Walker and Skogerboe 1987). The furrow cross-section was determined using a profile meter. Four parameters, top width, middle width, base, and maximum depth were measured. These values were entered in the SIRMOD model (Walker, 2003) to determine the hydraulic section ( $\rho_{1}$ and $\left.\rho_{2}\right)$ and furrow geometry $\left(\sigma_{1}\right.$ and $\left.\sigma_{2}\right)$ parameters corresponding to the monitored 
furrow in each treatment (Table 2). To assess the effects of the dispersivity $\left(D_{x}\right)$ on runoff nitrate concentrations, the model was run with different values $(1-100 \mathrm{~cm})$. The effect of $D_{x}$ on nitrate concentration was almost negligible in all cases. In this study, a value of $0.10 \mathrm{~m}$ was chosen for $D_{x}$ in all simulations based on the study reported by Abbasi et al. (2003c). In order to improve the simulation results, the parameters of the Kostiakov-Lewis equation were separately determined for each irrigation treatment and for each fertigation event (Table 2).

Model calibration only implied the estimation of the infiltration parameters. The average basic infiltration rate, $f_{o}$, was determined by the inflow-outflow method (Elliott and Walker 1987). The two-point method (Elliott and Walker 1982) was then used to determine parameters $a$ and $k$. The rest of model parameters was either physically measured or obtained from the literature. The validation of this model using field experiments was first reported by Abbasi et al. (2003c). In this paper, model validation was first based on the comparison of measured and simulated water runoff discharge and nitrate runoff concentration. Validation continued with the comparison of measured and simulated water and nitrate runoff ratios. The water runoff ratio is the fraction of the applied water that runs off the field. The nitrate runoff ratio is also the fraction of the applied nitrate that runs off the field. Finally, the Paired-Samples T Test procedure was used to statistically compare validation variables (Minitab Inc 1995). The test computes the differences between values of the two variables for each case and tests whether the average differs from zero. If the pvalue exceeds 0.05 , no significant differences can be established between measured and predicted data. Additional validation was performed by comparing Distribution Uniformity of the applied water: 
$D U_{W}=\frac{\text { Average of low }- \text { quarter water application }}{\text { Average water application }} \times 100$

The output of this fertigation model includes the time and space evolution of overland solute concentration, flow rate and velocity and flow area and depth. The advancerecession trajectories, the water and solute losses through runoff at the end of furrow and infiltration of water and fertilizer at each section of the furrow were also provided by the model. 


\section{Soil water and solute transport model}

The HYDRUS-2D model (Šimůnek et al. 1999b) was used to simulate water content and nitrate concentration in the soil. The governing flow equation is given by the following modified form of the Richards' equation:

$$
\frac{\partial \theta}{\partial t}=\frac{\partial}{\partial x_{i}}\left[K\left(K_{i j}{ }^{\Lambda} \frac{\partial h}{\partial x_{j}}+K_{i z}{ }^{\Lambda}\right)\right]-S
$$

where $\theta$ is the volumetric water content (dimensionless), $h$ is the pressure head [L], $S$ is a sink term $\left[\mathrm{T}^{-1}\right], x_{i}$ and $x_{j}$ are the spatial coordinates [L], $t$ is time [T], $K_{i j}{ }^{A}$ are components of a dimensionless anisotropy tensor $K^{A}$ and $K$ is the unsaturated hydraulic conductivity function $\left[\mathrm{L} \mathrm{T}^{-1}\right]$.

The HYDRUS-2D model implements the soil-hydraulic functions proposed by van Genuchten (1980) and Mualem (1976) to describe the soil water retention curve, $\theta(h)$, and the unsaturated hydraulic conductivity function, $K(h)$, respectively:

$$
\begin{aligned}
& \theta(h)=\left\{\begin{array}{cc}
\theta_{r}+\frac{\theta_{s}-\theta_{r}}{\left[1+|\alpha|^{N}\right]^{n}} & h<0 \\
\theta_{s} & h \geq 0
\end{array}\right. \\
& K(h)=K_{s} S_{e}^{l}\left[1-\left(1-S_{e}^{1 / m}\right)^{m}\right]^{2} \\
& m=1-1 / N, N>1 \\
& S_{e}=\frac{\theta-\theta_{r}}{\theta_{s}-\theta_{r}}
\end{aligned}
$$

Where $\theta_{r}$ and $\theta_{s}$ denote the residual and saturated water content, respectively (dimensionless); $\alpha$ is the inverse of the air-entry value $\left[\mathrm{L}^{-1}\right] ; K_{s}$ is the saturated hydraulic conductivity $\left[\mathrm{L} \mathrm{T}^{-1}\right], N$ is the pore-size distribution index (dimensionless), $S_{e}$ is the effective water content (dimensionless); and $l$ is the pore-connectivity 
parameter (dimensionless), with an estimated value of 0.5 , resulting from averaging conditions in a range of soils (Mualem 1976).

HYDRUS-2D numerically solves the convection-diffusion equation with zero- and first-order reaction and sink term. The Galerkin finite element method is used in this model to solve the governing equation subjected to appropriate initial and boundary conditions. In this paper, only $\mathrm{NO}_{3}{ }^{-}$transfer was simulated by solving the following equation:

$$
\frac{\partial \theta c}{\partial t}=\frac{\partial}{\partial x_{i}}\left(\theta D_{i j} \frac{\partial c}{\partial x_{j}}\right)-\frac{\partial q_{i} c}{\partial x_{i}}+\gamma_{w} \theta-S c_{s}
$$

where $c$ is the nitrate concentration in the soil $\left[\mathrm{M} \mathrm{L}^{-3}\right], q_{i}$ is the $\mathrm{i}$-th component of the volumetric flux $\left[\mathrm{L} \mathrm{T}^{-1}\right], D_{i j}$ is the dispersion coefficient tensor $\left[\mathrm{L}^{2} \mathrm{~T}^{-1}\right], \gamma_{w}$ is the zeroorder rate constant for nitrate production by ammonium degradation in the soil solution $\left[\mathrm{M} \mathrm{L}^{-3} \mathrm{~T}^{-1}\right], S$ is the sink term of the water flow in the Richards' equation, and $c_{S}$ is the concentration of the sink term $\left[\mathrm{M} \mathrm{L}^{-3}\right] . D_{i j}$ can be defined as follows:

$$
\theta D_{i j}{ }^{w}=D_{T}|q| \delta_{i j}+\left(D_{L}-D_{T}\right) \frac{q_{j} q_{i}}{|q|}+\theta D_{w} \tau_{w} \delta_{i j}
$$

Where $D_{w}$ is the molecular diffusion coefficient in free water $\left[\mathrm{L}^{2} \mathrm{~T}^{-1}\right] ; \tau_{w}$ is the tortuosity factor (dimensionless); $\delta_{i j}$ is the Kronecker delta function ( $\delta_{i j}=1$ if $i=j$, and $\delta_{i j}=0$ if $\left.i \neq j\right) ; D_{L}$ is the longitudinal dispersivity [L]; and $D_{T}$ is the transverse dispersivity [L]. As suggested in the manual of the HYDRUS-2D model for minimizing or eliminating numerical oscillations, the following condition was observed:

$\mathrm{PeCr} \leq 2$ 
The sink term $(S)$, represents the volume of water removed from a unit volume of soil per unit time, due to plant water uptake. This variable was determined according to the Feddes et al. (1978) approach, as implemented in the HYDRUS-2D model. Measured nitrate concentrations and soil water contents before each fertigation event were used as initial conditions within the flow domain. Maximum concentrations of nitrate in the sink term $c_{S}$ were estimated using the values obtained by Crevoisier et al. (2008). As a consequence, the nitrate $c_{s}$ values for the first and second fertigation events were chosen as 0.15 and $0.55 \mathrm{~kg} \mathrm{~m}^{-3}$, respectively, according to the evolution of plant height during the growing season. The simulation geometry and boundary conditions for conventional and alternate furrow irrigation is presented in Fig. 2.

The first fertigation event was used for the calibration of the soil water and solute transport model. A number of water flow and nitrate transport parameters were estimated using an inverse solution procedure implementing the LevenbergMarquardt optimization module built-in HYDRUS-2D (Šimůnek et al. 1999b). The inverse method is based on the minimization of a suitable objective function, which expresses the discrepancy between the observed and model predicted values. The objective function was defined as the sum of squared residuals (SSQ) (Šimůnek et al. 1999a):

$$
S S Q=\sum_{j=1}^{m} v_{j} \sum_{i=1}^{n} w_{i j}\left[q_{j}^{*}\left(x, z, t_{i}\right)-q_{j}\left(x, z, t_{i}, b\right)\right]^{2}
$$

Where $n$ is the number of measuremnets for the $\mathrm{j}^{\text {th }}$ measurement set (e.g., water contents, , concentrations, $\ldots) ; q_{i}^{*}\left(x, z, t_{i}\right)$ is the measurement at time $t_{i}$, location $x$, and depth $z ; q_{i}\left(x, z, t_{i}, b\right)$ is the corresponding model prediction obtained with the vector of optimized parameters $b=\left(\theta_{s}, K_{s} D_{L}, \ldots\right)$, and $v_{j}$ and $w_{i j}$ are weights associated with a particular measurement set or point, respectively. Weighting coefficients were 
assumed to be equal to 1 in all cases. Quality in parameter estimation was assessed using two dimensionless indicators: the coefficient of determination $\left(R^{2}\right)$ and $S S Q$.

Model predictions derive from the numerical solution of the flow equation, using the parameterized hydraulic functions, selected transport parameters, and suitable initial and boundary conditions. This approach has been successfully applied by several researchers (Abbasi et al. 2003b; Crevoisier et al. 2008; Verbist et al. 2009) to estimate hydraulic properties of soils. In this study, inverse estimation was applied to three water flow parameters, including $K_{s}$ (saturated hydraulic conductivity), $\theta_{s}$ (saturated soil water content) and $N$ (corresponding to the van Genuchten water retention function), and three nitrate transport parameters, including $D_{L}$ (longitudinal dispersivity), $D_{T}$ (transverse dispersivity) and $\gamma_{w}$ (zero-order production rate constant for dissolved phase). The $\gamma_{w}$ coefficient was applied to the process of ammonium nitrification in the soil (biological conversion of $\mathrm{NH}_{4}^{+}$to $\mathrm{NO}_{3}^{-}$). The ammonium transport was not simulated. The experimental data set only contained nitrate measurements. These measurements (and their temporal and spatial changes) were used to characterize the nitrification process. The $\alpha$ and $\theta_{r}$ parameters of the soil water retention curve were not determined using inverse estimation. These parameters were instead estimated using the Neural Network approach provided by HYDRUS-2D.

The second fertigation event was used for the validation of the combination of both models. The overland surface fertigation model was run with the calibrated infiltration parameters for the second fertigation event. HYDRUS-2D was used to simulate the second fertigation event using the parameters calibrated for the first fertigation event. Comparisons were established between field data and simulation output to assess the predictive capacity of the combined model.

\section{Model combination}


The overland and soil processes were dealt with in an uncoupled fashion. Infiltration of water and fertilizer was an output of the overland surface fertigation model and an input to the soil water and solute transport model. Consequently the overland surface fertigation model was run first, and then the soil water and solute transport model was run using the time-dependent results of the first model. 


\section{$\underline{\text { Results and discussions }}$}

\section{Overland surface fertigation model}

The model was run for the first and second fertigation events and for each irrigation strategy. The simulated runoff discharge and the nitrate concentration in the runoff water were compared with the measured data (Figs. 3 and 4 for the first and second fertigation event, respectively). The model succeeded in predicting these variables. This agreement supports the adequacy of the estimation of the infiltration parameters through the inflow and outflow hydrographs and the advance curves for each fertigation event and irrigation treatment. The agreement between simulated and measured runoff increased with time in both fertigation events. While measured data showed a gradual increase in runoff, model results showed a sharp increase (Fig. 3). This discrepancy may be due to the fact that the linear part of the cumulative infiltration equation (Eq. 3) was estimated with more accuracy than the non-linear part.

The nitrate concentration of the irrigation water at the furrow inlet (right after fertigation) was 398 and $245 \mathrm{mg} \mathrm{L}^{-1}$ for the first and second fertigation events, respectively. In the first fertigation event, nitrate concentration increased rapidly after the fertilizer injection. It took the fertilized water about 10 min to travel from the upstream to the downstream end of the furrow. In the second fertigation event, nitrate concentration was at the maximum when runoff started, since the fertilizer was applied since the onset of irrigation. In both cases, the predicted nitrate concentrations were almost constant whereas the measured values showed some fluctuations. These variations could be related to small changes in water and fertilizer rates in the field 
(Abbasi et al. 2003c), to the interaction between fertilized water and the soil surface, and to experimental errors in nitrate determination.

Only small differences in runoff nitrate concentration could be appreciated between the different irrigation methods. However, fertilizer runoff losses were higher for CFI than for AFI and FFI. This was due to the large differences in infiltration between CFI on one hand and AFI and FFI on the other. Differences in fertilizer runoff losses would probably increase with furrow length. Small differences could be observed between measured and simulated AFI and FFI runoff. Higher infiltration (due to increased lateral flow) resulted in lower runoff at the alternate furrow treatments, as compared to conventional furrow irrigation. Sepaskhah and Afshar-Chamanabad (2002) and Slatni et al. (2011) also reported higher infiltration in alternate furrow irrigation than in CFI. Water and nitrate runoff losses were relatively high due to the large difference between cut-off time and advance time. In such short furrows, the closed-end furrow practice could be used as a technique to promote water conservation.

Adequate correlation was found between the measured and predicted water and nitrate runoff ratios for all six irrigation cases (first and second fertigation, three irrigation treatments) (Fig. 5). Linear equations $(y=a x+b)$ were fitted using statistical regression. The resulting regression lines were significant at the $95 \%$ probability level. The slope $(a)$ and the interception $(b)$ of the regression lines for water and nitrate could not be distinguished from 1 and 0 , respectively. As a consequence, the regression line could not be distinguished from the 1:1 line, indicating adequate model validation. The model performed better for overland water flow than for nitrate transport. The $R^{2}$ values were 0.972 and 0.753 for water and nitrate, respectively. The Paired-Samples T Test procedure for water and nitrate runoff ratios showed $\mathrm{p}$-values 
exceeding the 0.05 threshold, thus excluding the existence of significant differences between these variables. Significant differences could not be established between measured and predicted runoff discharge and nitrate concentration, considering all irrigation treatments and both fertigation events (scatter plots not presented).

Water distribution uniformity $\left(D U_{W}\right)$ was experimentally determined from infiltrated volume along the furrow using the opportunity times and the infiltration equation. $D U_{W}$ was also determined by the overland simulation model. In the case of nitrate application, the model provided an estimate of nitrate uniformity $\left(D U_{N}\right)$, which could not be determined from the experimental data. High water distribution uniformity was obtained in all irrigation treatments and in both fertigation events using field measurements and model predictions (Fig. 6). Measured $D U_{W}$ ranged from 95.7 to $98.0 \%$, while the predicted values ranged from 89.2 to $94.8 \%$. While the measured values were systematically higher than the simulated values (by an average difference of 4.7 basic points), a good correspondence was observed between both variables. Model predicted $D U_{N}$ for AFI, FFI and CFI were 90.7, 94.8 and 90.5 in the first fertigation, and 90.7, 91.5 and 93.7 in the second fertigation, respectively. Very high fertilizer uniformity was obtained in the experimental field in all cases. Short furrows and a long filling phase help attaining high $\mathrm{DU}_{\mathrm{N}}$.

\section{Soil water and solute transport model}

The inverse model solution was obtained for a homogeneous soil profile (i.e. a single $0.6 \mathrm{~m}$ layer). HYDRUS-2D could not converge for estimating the parameters of the three layers reported in Table 1 due to insufficient measured data. Calibrations were performed for three sections of the experimental furrows (upstream, middle and downstream) and for each irrigation treatment. 
The soil hydraulic and solute transport parameters were simultaneously estimated. This method presents the advantage of considering interactive effects between the water flow and solute transport parameters. The inverse optimization method simultaneously uses all measured data, i.e., water contents and nitrate concentrations, and yields better estimation than sequential optimization (Abbasi et al. 2003b; Šimůnek et al. 2002). The optimized values of the soil hydraulic and nitrate transport parameters for the upstream, middle and downstream of each irrigation treatment are presented in Table 3 . These parameter values resulted in minimum error between the observed and simulated values. The $R^{2}$ and SSQ indicators attained satisfactory values in all cases.

The ranges of optimum $K_{s}, \theta_{s}$ and $N$ values were $0.44-3.69 \mathrm{~cm} \mathrm{~h}^{-1}, 0.350-0.517 \mathrm{~cm}^{3}$ $\mathrm{cm}^{-3}$ and 1.22-2.07, respectively. The optimized $D_{L}$ values varied between 0.54 and $7.82 \mathrm{~cm}$, while optimum $D_{T}$ ranged from 0.00 to $2.10 \mathrm{~cm}$. The optimized $\gamma_{\mathrm{w}}$ values ranged 0.00107 to $0.00153\left(\mathrm{mg} \mathrm{cm}^{-3} \mathrm{~h}^{-1}\right)$. Hanson et al. (2006) stated that $\gamma_{\mathrm{w}}$ had been reported in the literature to range from 0.001 to $0.03 \mathrm{mg} \mathrm{cm}^{-3} \mathrm{~h}^{-1}$. Crevoisier et al. (2008) reported ranges from $5.10^{-7}$ to $0.005 \mathrm{mg} \mathrm{cm}^{-3} \mathrm{~h}^{-1}$ for furrow irrigation under fertilization.

The reported values of these six parameters in every irrigation treatment and furrow section led to the estimation of values of water content and nitrate concentration reproducing the measured data. Additionally, the optimum values of the parameters are sensible and fit in the common ranges reported in the literature. The differences between irrigation treatments and furrow locations may be due to the different application times of water and fertilizer in addition to the spatially variable soil hydraulic and solute transport parameters (Abbasi et al. 2004). 
The validation process involved running the combined model for the conditions of the second fertigation with the optimized values obtained by the inverse solution from the first fertigation. Model results were evaluated using the measured data in August 11 and 15 (two and six days after the fertigation event, respectively). All measured and predicted values of water content and nitrate concentration are confronted in Fig. 7. Significant regressions were established between measured and predicted values for water content and nitrate concentration. The $R^{2}$ values for the AFI, FFI and CFI treatments were $0.721,0.795$ and 0.767 for water content and $0.798,0.781$ and 0.684 for nitrate concentration, respectively. The six regression lines presented in Fig. 7 were analyzed for similitude with the $1: 1$ line. The results were very positive, with the only exception of the intercept in CFI for water and the intercept and slope in AFI for nitrate. Significant differences could not be established in any case between measured and predicted values of water content and nitrate concentration according to the Paired-Samples T Test procedure ( $\mathrm{p}$-value $>0.05)$.

Graphical comparisons between measured and simulated profiles of water content at the upstream, middle and downstream sections of the field are presented in Figs. 8 and 9 for all irrigation treatments and for two and six days after the fertigation, respectively. The model succeeded in simulating the redistribution process for water in different depths and cross sections (wet and dry furrow bottoms and furrow ridge). Adequate agreement was found between measured and predicted values.

Figs. 10 and 11 present measured and simulated soil nitrate concentrations for all irrigation treatments. The figures present data corresponding to two and six days after the fertigation event for all three furrow sections and all three irrigation treatments. . The figures confirm the capacity of the combined model to simulate the spatial and temporal variations of the nitrate concentration in an adequate fashion. 
The measured and predicted values of water content and nitrate concentration were higher at the upstream section of the furrows (all irrigation treatments) than at the middle and downstream sections. In fact, water contents and nitrate concentrations decreased with increasing distance from the upstream furrow end. These results are in agreement with the differences in opportunity time and with the local infiltration at the time of passage of the fertilized water. As expected, wet furrows were found to have more soil water content and nitrate concentration than the ridge and dry furrows.

The combination of both models succeeded in simulating the overland and underground processes of furrow fertigation not only for the conventional practice, but also for alternate furrow irrigation. These findings extend the previous results reported by Crevoisier et al. (2008) and Abbasi et al. (2004) also reported that HYDRUS-2D could successfully simulate alternate and conventional furrow irrigation and fertigation in conventional furrow irrigation, respectively. 


\section{Conclusions}

This study focuses on the simulation of water flow and fertilizer transport in two types of alternate furrow irrigation and conventional furrow irrigation under fertigation. A 1D surface fertigation model (Abbasi et al. 2003c) and a 2D subsurface water and solute transport model (HYDRUS-2D) were used for this purpose, basing calibrationvalidation on an experimental data set. The models were combined in an uncoupled fashion, with the surface fertigation model being run first, and HYDRUS-2D running on the results of the first model.

The surface fertigation model was calibrated by estimation of the infiltration parameters for both fertigation events. Both the measured and predicted values indicated that the alternate furrow irrigation could reduce water and fertilizer losses in runoff. Adequate agreement was found between the measured and predicted runoff discharge and nitrate concentration. Although water and fertilizer movement in furrow irrigation is two-dimensional, particularly in the case of alternate furrow irrigation, the 1D surface fertigation model could successfully simulate fertigation in all irrigation treatments.

HYDRUS-2D was calibrated and validated for the first and second fertigation events, respectively. The calibration of this model was done by estimating the soil hydraulic and solute transport parameters using its inverse solution approach. HYDRUS-2D could adequately simulate the temporal and spatial distribution of water content and nitrate concentration at the irrigated and non-irrigated furrow bottoms and at the ridge. HYDRUS-2D not only showed adequate performance for conventional furrow irrigation, but also for alternate furrow irrigation. 
The combined model stands as a valuable tool to better design and manage fertigation in alternate and conventional furrow irrigation, thus contributing to the mitigation of the water crisis and to the control of environmental risks. Moreover, the results of this study could support farmers' application of alternate furrow irrigation for water and fertilizer conservation.

\section{Acknowledgment}

This research was funded by The Center of Excellence for Evaluation and Rehabilitation of Irrigation and Drainage Networks of the University of Tehran. Thanks are due to Jiri Šimůnek, Dept. of Environmental Sciences, Univ. of California, for his helpful comments and suggestions. 


\section{References}

Abbasi F, Shooshtari MM, Feyen J (2003a) Evaluation of various surface irrigation numerical simulation models. J Irrigation Drainage Eng 129(3):208-213

Abbasi F, Šimůnek J, Feyen J, van Genuchten MTh, Shouse PJ (2003b) Simultaneous inverse estimation of the soil hydraulic and solute transport parameters from transient field experiments: homogeneous soil. Transactions ASAE 46(4):10851095

Abbasi F, Šimůnek J, Genuchten V, Feyen J, Adamsen FJ, Hunsaker DJ, Strelkoff TS, Shouse P (2003c) Overland water flow and solute transport: model development and field-data analysis. J Irrigation Drainage Eng 129(2):71-81

Abbasi F, Feyen J, van Genuchten MT (2004) Two dimensional simulation of water flow and solute transport below furrows: model calibration and validation. $\mathrm{J}$ Hydrology 290:63-79

Adamsen FJ, Hunsaker DJ, Perea H (2005) Border strip fertigation: Effect of injection strategies on the distribution of bromide. Transactions ASAE 48(2):529-540

Benjamin JG, Havis HR, Ahuja LR, Alonso CV (1994) Leaching and water flow patterns in every-furrow and alternate-furrow irrigation. Soil Sci Soc Am $58: 1511-1517$

Boldt AL, Watts DG, Eisenhauer DE, Schepers JS (1994) Simulation of water applied nitrogen distribution under surge irrigation. Transactions ASAE 37(4):11571165

Burguete J, Zapata N, García-Navarro P, Maïkaka M, Playán E, Murillo J (2009) Fertigation in Furrows and Level Furrow Systems. II: Field Experiments, Model Calibration, and Practical Applications. J Irrigation Drainage Eng 135(4):413- 
Crevoisier D, Popova Z, Mailhol JC, Ruelle P (2008) Assessment and simulation of water and nitrogen transfer under furrow irrigation. Agric Water Manag $95: 354-366$

Cunge JA, Holly FM, Verwey A (1980) Practical aspects of computational river hydraulics. Pitman, London.

Ebrahimian H, Liaghat A, Parsinejad M, Playán E (201X) Water and nitrate distribution and losses under alternate and conventional furrow fertigation. Agric Water Manag. Submitted.

Elliott RL, Walker WR (1982) Field evaluation of furrow infiltration and advance functions. Transactions ASAE 25(2):396-400

Feddes RA, Kowalik PJ, Zaradny H (1978) Simulation of Field Water Use and Crop Yield. John Wiley \& Sons, New York, NY

Hanson BR, Šimůnek J, Hopmans JW (2006) Evaluation of urea-ammonium-nitrate fertigation with drip irrigation using numerical modeling. Agric Water Manag $86: 102-113$

Horst MG, Shamutalov SS, Goncalves JM, Pereira LS (2007) Assessing impacts of surge-flow irrigation on water saving and productivity of cotton. Agric Water Manag 87:115-127

Izadi B, King B, Westerman D, McCann I (1996) Modeling transport of bromide in furrow irrigation field. J Irrigation Drainage Eng 122(2):90-96

Kang S, Lianga Z, Panb Y, Shic P, Zhangd J (2000) Alternate furrow irrigation for maize production in an arid area. Agric Water Manag 45:267-274

Mailhol JC, Ruelle P, Nemeth I (2001) Impact of fertilization practices on nitrogen 
leaching under irrigation. Irrigation Sci 20:139-147

Minitab Inc (1995) The student edition of MINITAB for Windows. Addison-Wesley Publishing Co. State College, PA.

Mualem Y (1976) A new model for predicting the hydraulic conductivity of unsaturated porous media. Water Resour Res 12(3): 513-522.

Ongley ED (1996) Control of water pollution from agriculture. FAO Irrigation and Drainage Paper No. 55

Perea H, Strelkoff TS, Adamsen FJ, Hunsaker DJ, Clemmens AJ (2010) Nonuniform and Unsteady Solute Transport in Furrow Irrigation I: Model Development. J Irrigation Drainage Eng 136(6):365-375

Playán E, Faci JM (1997) Border fertigation: field experiment and a simple model. Irrigation Sci 17:163-171

Sabillón GN, Merkley GP (2004) Fertigation guidelines for furrow irrigation. Spanish Agric Res 2:576-587

Seckler D, Molden D, Sakthivadivel R (2003) The concept of efficiency in water resources management and policy. In: Kijne JW, Barker R, Molden D (Eds.) Water productivity in agriculture: Limits and opportunities for improvement. CABI Publishing, UK, (in association with IWMI, Colombo, Sri Lanka), pp. $37-51$

Sepaskhah AR (2010) Organic agriculture and water and fertilizer productivities. Conference of Organic Agriculture, Academy of Sciences, Tehran, Iran [In Persian]

Sepaskhah AR, Afshar-Chamanabad H (2002) Determination of infiltration rate for every-other furrow irrigation. Biosyst Eng 82(4) : 479-484 
Šimůnek J, Jacques D, Hopmans JW, Inoue M, Flury M, van Genuchten MTh (2002) Solute transport during variably-saturated flow- Inverse methods. Chapter 6.6 in Methods of Soil Analysis: Part 1. Physical Methods, 1435-1449. 3rd ed. J. H. Dane and G. C. Topp, eds. Madison, Wisc.: SSSA.

Šimůnek J, Kodesova R, Gribb MM, Van Genuchten MTh (1999a) Estimating hysteresis in the soil water retention function from cone permeameter experiments. Water Resour Res 35(5):1329-1345

Šimůnek J, Sejna M, van Genuchten MTh (1999b) The HYDRUS-2D software package for simulating the two dimensional movement of water, heat, and multiple solutes in variably saturated media, Version 2.0, IGWMC-TPS-700, Int. Ground Water Modeling Center, Colorado School of Mines, Golden, Co.

Šimůnek J, Vogel T, van Genuchten MTh (1994) The SWMS_2D Code for simulating water flow and solute transport in tow dimensional variably saturated media (Version 1.21). Research Report No. 132. US Salinity Laboratory Agricultural Research Service, US Department of Agriculture, Riverside, California

Slatni A, Zayani K, Zairi A, Yacoubi S, Salvador R, Playán E (2011) Assessing alternate furrow strategies for potato at the Cherfech irrigation district of Tunisia. Biosyst Eng 108(2):154-163

Smith M (1992) CROPWAT- A computer program for irrigation planning and management. FAO Irrigation and Drainage paper 46

Thind HS, Buttar GS, Aujla MS (2010) Yield and water use efficiency of wheat and cotton under alternate furrow and check-basin irrigation with canal and tube well water in Punjab, India. Irrigation Sci 28:489-496

van Genuchten MT (1980) A closed form equation for predicting the hydraulic 
conductivity of unsaturated soils. Soil Sci Soc Am 44:892-898

Verbist K, Cornelis WM, Gabriels D, Alaerts K, Soto G (2009) Using an inverse modeling approach to evaluate the water retentioin in a simple water harvesting technique. Hydrol Earth Syst Sci 13:1979-1992.

Walker WR (2003) SIRMOD III- Surface irrigation simulation, evaluation and design. Guide and technical documentation. Dept. of Biological and Irrigation Engineering. Utah St. Univ., Logan, UT, USA.

Walker WR, Skogerboe G (1987) Surface Irrigation: Theory and Practice. PrenticeHall, Englewood Cliffs, N.J.

Wöhling Th, Mailhol JC (2007) Physically based coupled model for simulating 1D surface-2D subsurface flow and plant water uptake in irrigation furrows. II: Model test and evaluation. J Irrigation Drainage Eng 133(6):548-558

Wöhling Th, Schmitz GH (2007) Physically based coupled model for simulating 1D surface-2D subsurface flow and plant water uptake in irrigation furrows. I: Model development. J Irrigation Drainage Eng 133(6):538-547 


\section{List of Tables:}

Table 1. Soil physical properties determined at the upstream, middle and downstream parts of the experimental field.

Table 2. Input values of the parameters governing the overland surface fertigation model for all irrigation treatments and both fertigation events.

Table 3. Summary of the optimized soil hydraulic and nitrate transport parameters for the different irrigation treatments. 


\section{$\underline{\text { List of Figures }}$}

Fig. 1. Layout of the fixed alternate furrow irrigation treatment (FFI), showing: a) the furrow layout and the three types of furrows; and b) a schematic representation of the fertilizer solution injection system.

Fig. 2. Schematic representation of the boundary conditions used in HYDRUS-2D for conventional and alternate furrow irrigation treatments

Fig. 3. Measured and predicted runoff discharge and nitrate $\left(\mathrm{NO}_{3}{ }^{-}\right)$concentration for all irrigation treatments in the first fertigation event.

Fig. 4. Measured and predicted runoff discharge and nitrate $\left(\mathrm{NO}_{3}{ }^{-}\right)$concentration for all irrigation treatments in the second fertigation event.

Fig. 5. Measured and predicted runoff ratio for water and nitrate in both fertigation events.

Fig. 6. Distribution uniformity of water (measured and predicted) and nitrate (predicted) in both fertigation events.

Fig. 7. Measured and predicted soil water content and nitrate concentration in the second fertigation for the three irrigation treatments.

Fig. 8. Measured and predicted water content profiles below the wet and dry furrow bottoms and the furrow ridge for all irrigation treatments two days after the second fertigation event (11 August).

Fig. 9. Measured and predicted water content profiles below the wet and dry furrow bottoms and the furrow ridge for all irrigation treatments six days after the second fertigation event (15 August).

Fig. 10. Measured and predicted nitrate $\left(\mathrm{NO}_{3}{ }^{-}\right)$concentration profiles below the wet and dry furrow bottoms and the furrow ridge for all irrigation treatments two days after the second fertigation event (11 August). 
Fig. 11. Measured and predicted nitrate $\left(\mathrm{NO}_{3}{ }^{-}\right)$concentration profiles below the wet and dry furrow bottoms and the furrow ridge for all irrigation treatments six days after the second fertigation event (15 August). 
Table 1. Soil physical properties determined at the upstream, middle and downstream parts of the experimental field.

\begin{tabular}{|c|c|c|c|c|c|c|c|c|}
\hline \multirow[b]{2}{*}{ Location } & \multirow{2}{*}{$\begin{array}{l}\text { Depth } \\
\text { (m) }\end{array}$} & \multirow{2}{*}{$\begin{array}{c}\text { Texture } \\
\text { classification } \\
\text { (USDA) }\end{array}$} & \multicolumn{3}{|c|}{ Soil particles (\%) } & \multirow{2}{*}{$\begin{array}{c}\text { Bulk } \\
\text { density } \\
\left(\mathrm{Mg} \mathrm{m}^{-3}\right)\end{array}$} & \multirow{2}{*}{$\begin{array}{c}\text { Field } \\
\text { Capacity } \\
\left(\mathrm{kg}^{3} \mathrm{~kg}^{-3}\right)\end{array}$} & \multirow{2}{*}{$\begin{array}{c}\text { Wilting } \\
\text { Point } \\
\left(\mathrm{kg}^{3} \mathrm{~kg}^{-3}\right)\end{array}$} \\
\hline & & & $\begin{array}{l}\text { Clay } \\
(\%)\end{array}$ & $\begin{array}{l}\text { Silt } \\
(\%)\end{array}$ & $\begin{array}{l}\text { Sand } \\
(\%)\end{array}$ & & & \\
\hline \multirow{3}{*}{ 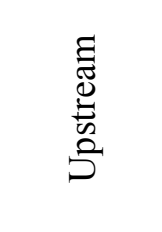 } & $0.0-0.2$ & clay loam & 28.5 & 35.0 & 36.5 & 1.50 & 0.182 & 0.087 \\
\hline & $0.2-0.4$ & clay loam & 28.5 & 33.8 & 37.8 & 1.45 & 0.175 & 0.081 \\
\hline & $0.4-0.6$ & sandy loam & 16.0 & 17.5 & 66.5 & 1.47 & 0.142 & 0.060 \\
\hline \multirow{3}{*}{$\frac{0}{\frac{\theta}{g}}$} & $0.0-0.2$ & loam & 26.0 & 30.0 & 44.0 & 1.50 & 0.181 & 0.085 \\
\hline & $0.2-0.4$ & $\begin{array}{c}\text { sandy clay } \\
\text { loam }\end{array}$ & 23.5 & 25.0 & 51.5 & 1.45 & 0.172 & 0.080 \\
\hline & $0.4-0.6$ & $\begin{array}{l}\text { sandy clay } \\
\text { loam }\end{array}$ & 21.0 & 22.5 & 56.5 & 1.52 & 0.155 & 0.069 \\
\hline \multirow{3}{*}{ 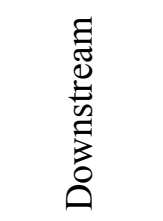 } & $0.0-0.2$ & clay loam & 31.0 & 31.7 & 37.3 & 1.51 & 0.181 & 0.084 \\
\hline & $0.2-0.4$ & loam & 26.8 & 30.4 & 42.8 & 1.48 & 0.177 & 0.081 \\
\hline & $0.4-0.6$ & sandy loam & 20.2 & 24.6 & 55.3 & 1.49 & 0.150 & 0.066 \\
\hline
\end{tabular}


Table 2. Input values of the parameters governing the overland surface fertigation model for all irrigation treatments and both fertigation events.

\begin{tabular}{|c|c|c|c|c|c|c|}
\hline \multirow{2}{*}{ Parameters } & \multicolumn{3}{|c|}{ First fertigation } & \multicolumn{3}{|c|}{ Second fertigation } \\
\hline & AFI & FFI & CFI & AFI & FFI & CFI \\
\hline Inflow rate $\left(\mathrm{L} \mathrm{s}^{-1}\right)$ & 0.262 & 0.262 & 0.262 & 0.388 & 0.388 & 0.388 \\
\hline Time of cut-off (min) & 240 & 240 & 240 & 360 & 360 & 360 \\
\hline Start time of injection (min) & 51.3 & 49.7 & 48.2 & 0 & 0 & 0 \\
\hline Duration of injection (min) & 150 & 150 & 150 & 180 & 180 & 180 \\
\hline \multicolumn{7}{|l|}{ Hydraulic section parameters ${ }^{a}$} \\
\hline$\rho_{1}\left(\mathrm{~m}^{3.33-2 \rho}{ }_{2}\right)$ & 0.311 & 0.302 & 0.192 & 0.260 & 0.302 & 0.192 \\
\hline$\rho_{2}$ (dimensionless) & 2.737 & 2.733 & 2.628 & 2.694 & 2.733 & 2.628 \\
\hline \multicolumn{7}{|l|}{ Furrow geometry parameters ${ }^{b}$} \\
\hline$\sigma_{1}\left(\mathrm{~m}^{1 / 2 \sigma 2}\right)$ & 0.934 & 1.064 & 1.075 & 0.898 & 1.064 & 1.075 \\
\hline$\sigma_{2}($ dimensionless $)$ & 1.544 & 1.587 & 1.584 & 1.491 & 1.587 & 1.584 \\
\hline \multicolumn{7}{|l|}{ Kostiakov-Lewis parameters } \\
\hline$K\left(\mathrm{~m}^{3} \min ^{-1} \mathrm{~m}^{-1}\right)$ & 0.0037 & 0.0038 & 0.0035 & 0.0073 & 0.0061 & 0.0090 \\
\hline$a$ (dimensionless) & 0.137 & 0.125 & 0.174 & 0.094 & 0.137 & 0.066 \\
\hline$f_{o}\left(\mathrm{~m}^{3} \min ^{-1} \mathrm{~m}^{-1}\right)$ & 0.000112 & 0.000106 & 0.000088 & 0.000140 & 0.000132 & 0.000068 \\
\hline
\end{tabular}


Table 3. Summary of the optimized soil hydraulic and nitrate transport parameters for the different irrigation treatments.

\begin{tabular}{|c|c|c|c|c|c|c|c|c|c|}
\hline \multirow[b]{2}{*}{ Irrigation } & \multirow[b]{2}{*}{$\begin{array}{l}\text { furrow } \\
\text { location }\end{array}$} & \multicolumn{3}{|c|}{ Soil hydraulic parameters } & \multicolumn{3}{|c|}{ Nitrate transport parameters } & \multirow[b]{2}{*}{$\begin{array}{l}R^{2} \\
(-)\end{array}$} & \multirow[b]{2}{*}{$\begin{array}{c}S S Q \\
(-)\end{array}$} \\
\hline & & $\begin{array}{l}\Theta_{\mathrm{S}} \\
(-)\end{array}$ & $\begin{array}{l}n \\
(-)\end{array}$ & $\begin{array}{c}K_{s} \\
\left(\mathrm{~cm} \mathrm{~h}^{-1}\right)\end{array}$ & $\begin{array}{c}D_{L} \\
(\mathrm{~cm})\end{array}$ & $\begin{array}{c}D_{T} \\
(\mathrm{~cm})\end{array}$ & $\begin{array}{c}\gamma_{\mathrm{w}} \\
\left(\mathrm{mg} \mathrm{cm}^{-3} \mathrm{~h}^{-1}\right)\end{array}$ & & \\
\hline \multirow{3}{*}{ AFI } & upstream & 0.372 & 1.31 & 2.52 & 0.54 & 0.10 & 0.00133 & 0.768 & 0.537 \\
\hline & middle & 0.365 & 1.53 & 1.19 & 4.27 & 0.00 & 0.00126 & 0.690 & 0.730 \\
\hline & downstream & 0.350 & 1.47 & 1.20 & 2.36 & 0.35 & 0.00109 & 0.748 & 0.692 \\
\hline \multirow{3}{*}{ FFI } & upstream & 0.405 & 1.97 & 0.76 & 1.26 & 1.67 & 0.00133 & 0.799 & 0.480 \\
\hline & middle & 0.382 & 1.30 & 2.39 & 7.82 & 0.40 & 0.00112 & 0.912 & 0.104 \\
\hline & downstream & 0.350 & 1.22 & 3.69 & 5.79 & 1.21 & 0.00107 & 0.819 & 0.45 \\
\hline \multirow{3}{*}{ CFI } & upstream & 0.517 & 1.71 & 2.63 & 2.94 & 2.10 & 0.00153 & 0.639 & 0.828 \\
\hline & middle & 0.350 & 1.43 & 1.42 & 3.73 & 0.91 & 0.00127 & 0.764 & 0.667 \\
\hline & downstream & 0.389 & 2.07 & 0.44 & 1.38 & 0.25 & 0.00124 & 0.866 & 0.320 \\
\hline
\end{tabular}


Fig. 1. Layout of the fixed alternate furrow irrigation treatment (FFI), showing: a) the furrow layout and the three types of furrows; and b) a schematic representation of the fertilizer solution injection system.

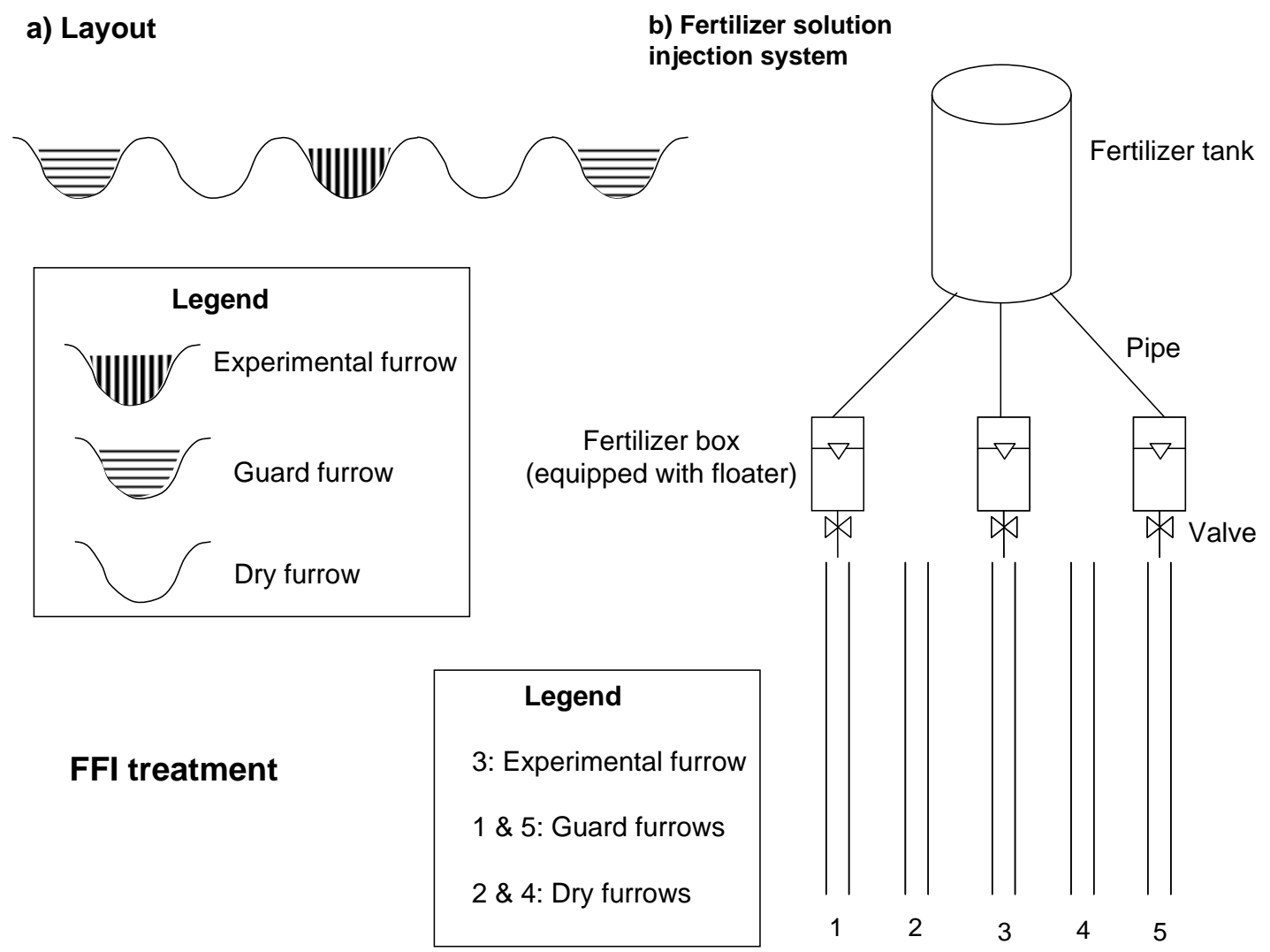


Fig. 2. Schematic representation of the boundary conditions used in HYDRUS-2D for conventional and alternate furrow irrigation treatments.

a) $\mathrm{CFI}$

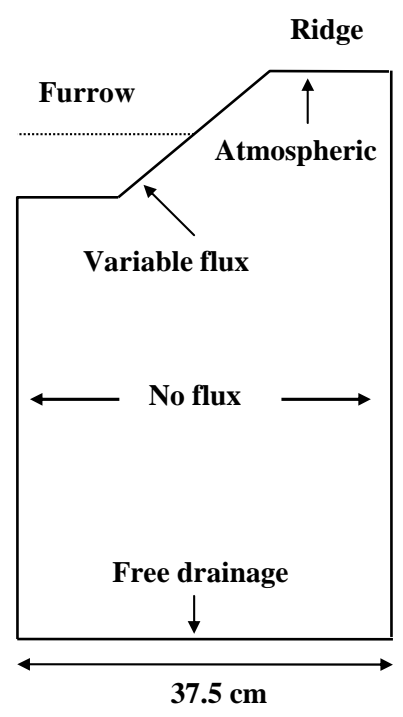

b) AFI and FFI

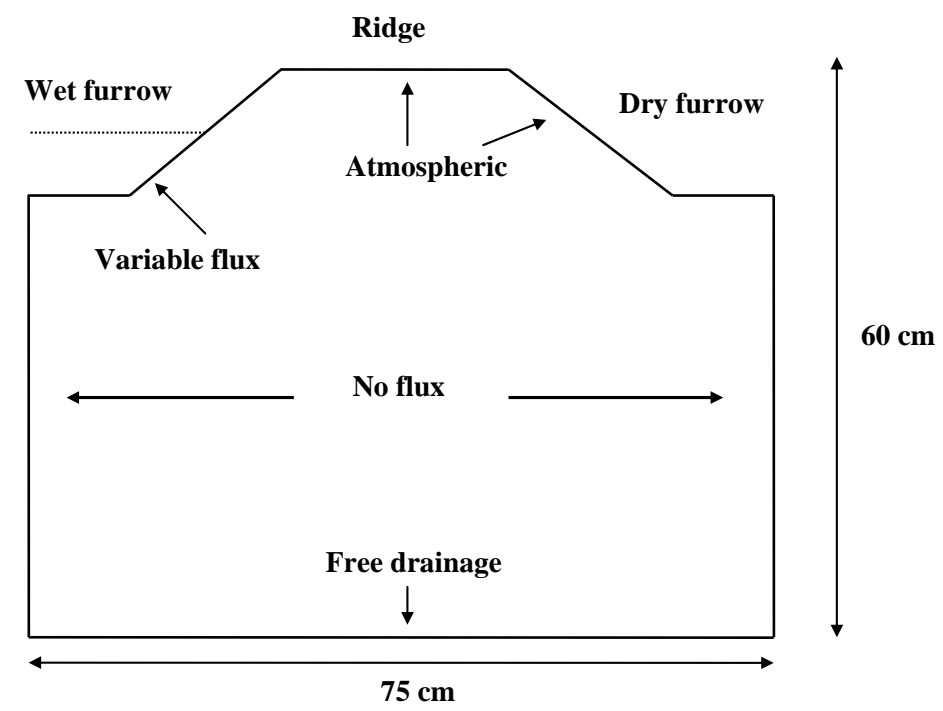


Fig. 3. Measured and predicted runoff discharge and nitrate $\left(\mathrm{NO}_{3}{ }^{-}\right)$concentration for all irrigation treatments in the first fertigation event.
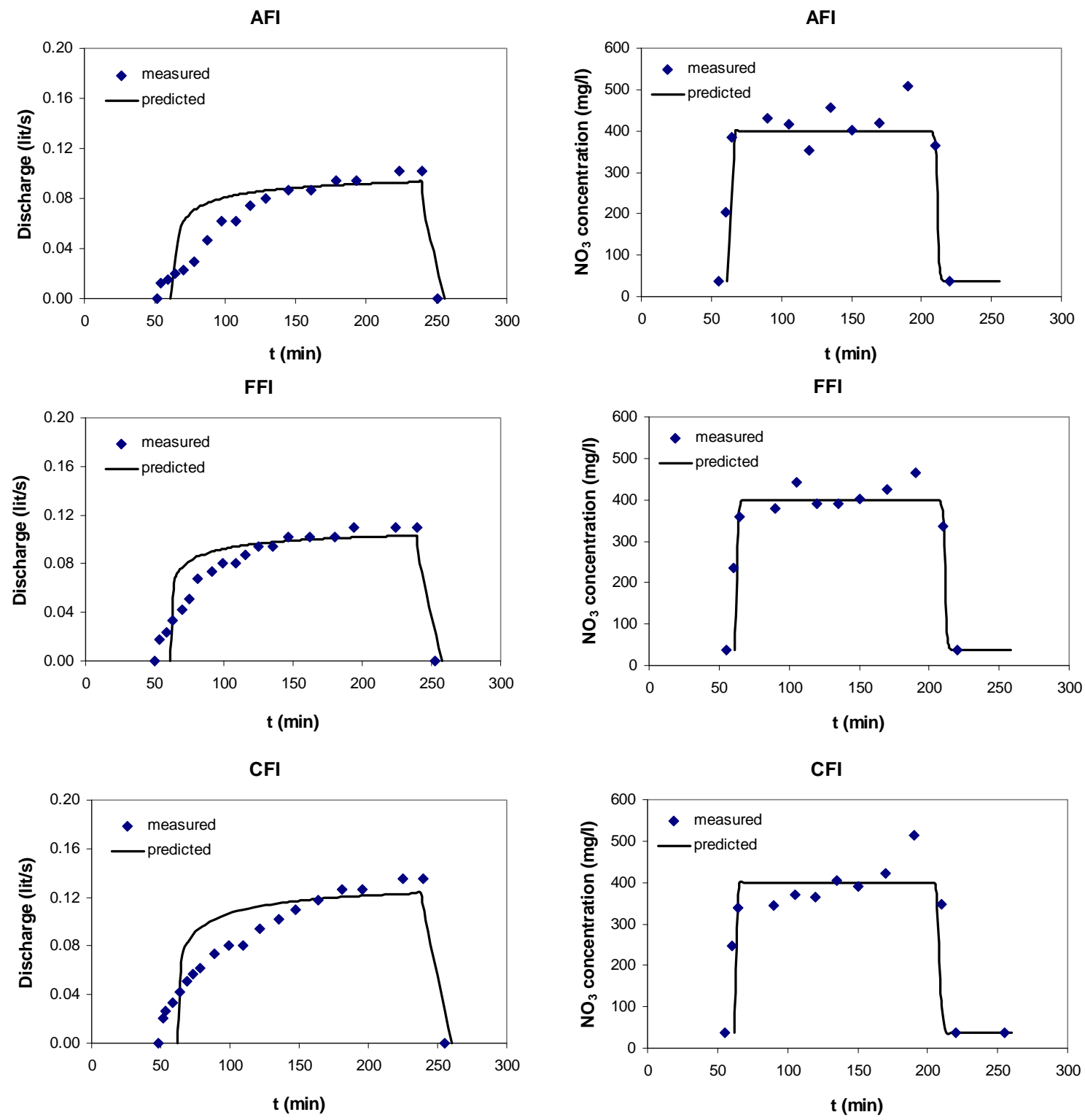
Fig. 4. Measured and predicted runoff discharge and nitrate $\left(\mathrm{NO}_{3}{ }^{-}\right)$concentration for all irrigation treatments in the second fertigation event.
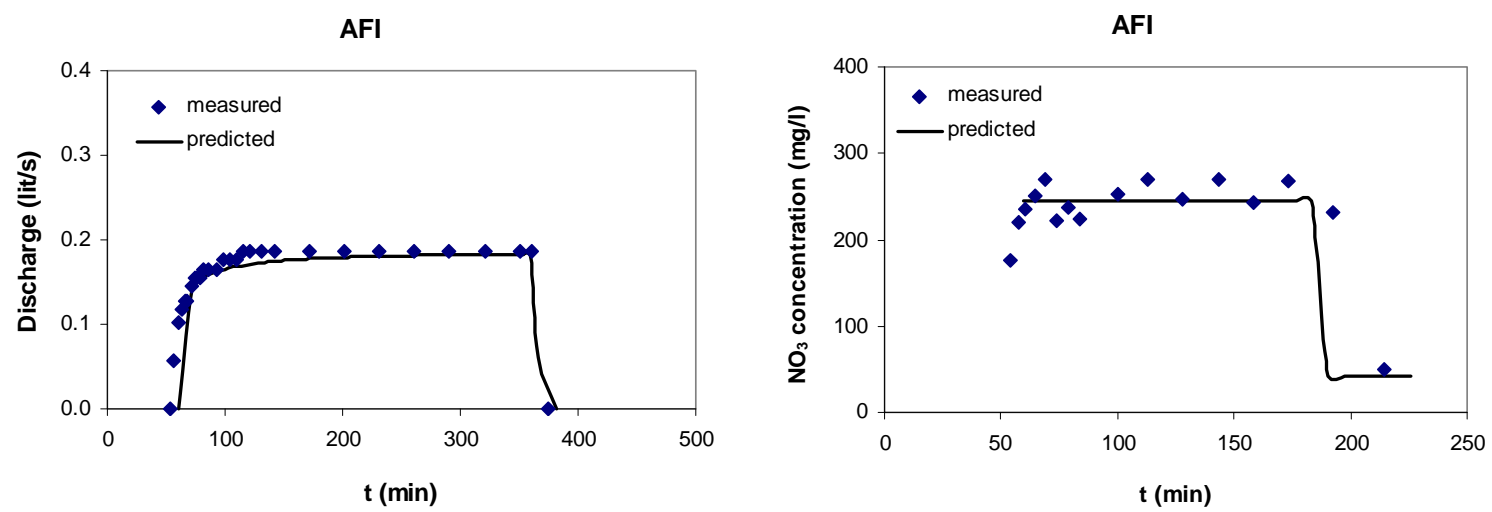

FFI
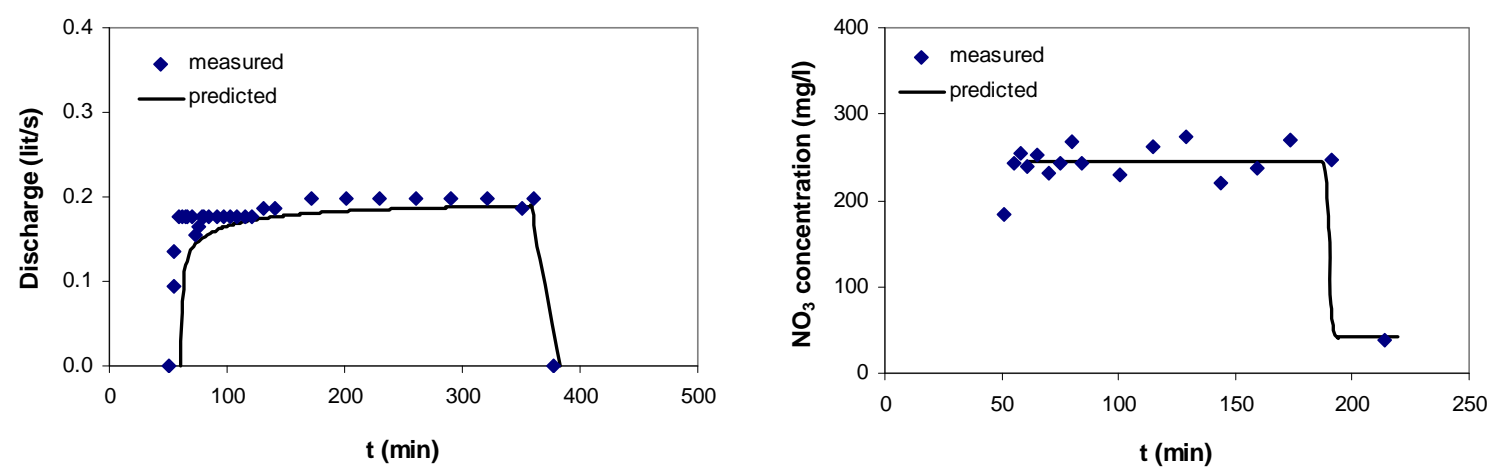

CFI
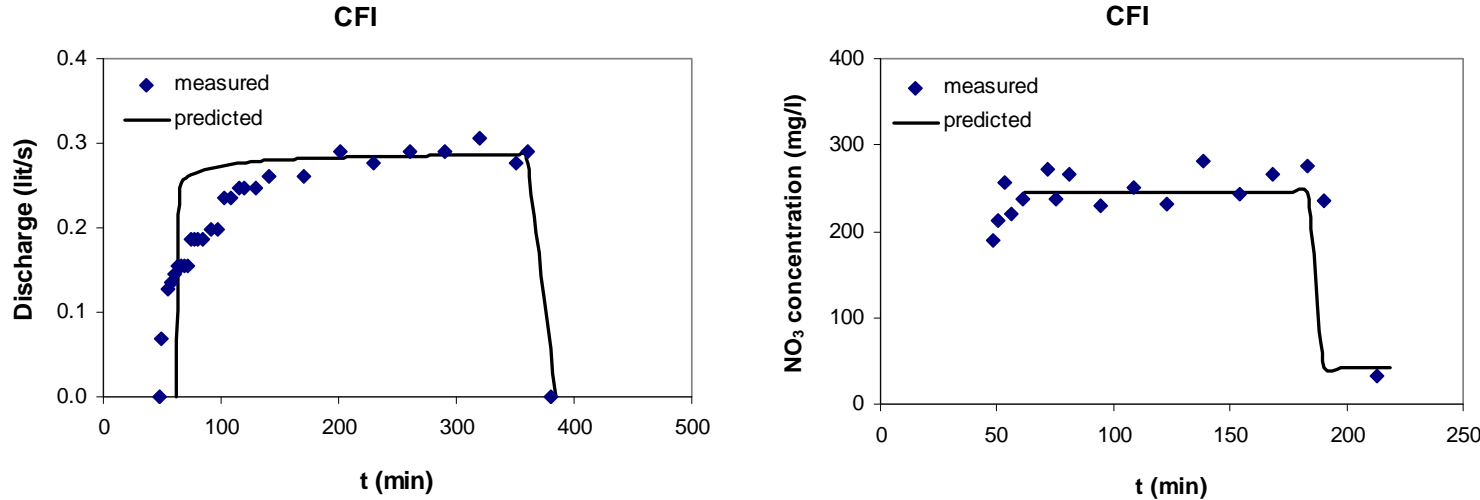
Fig. 5. Measured and predicted runoff ratio for water and nitrate in both fertigation events.
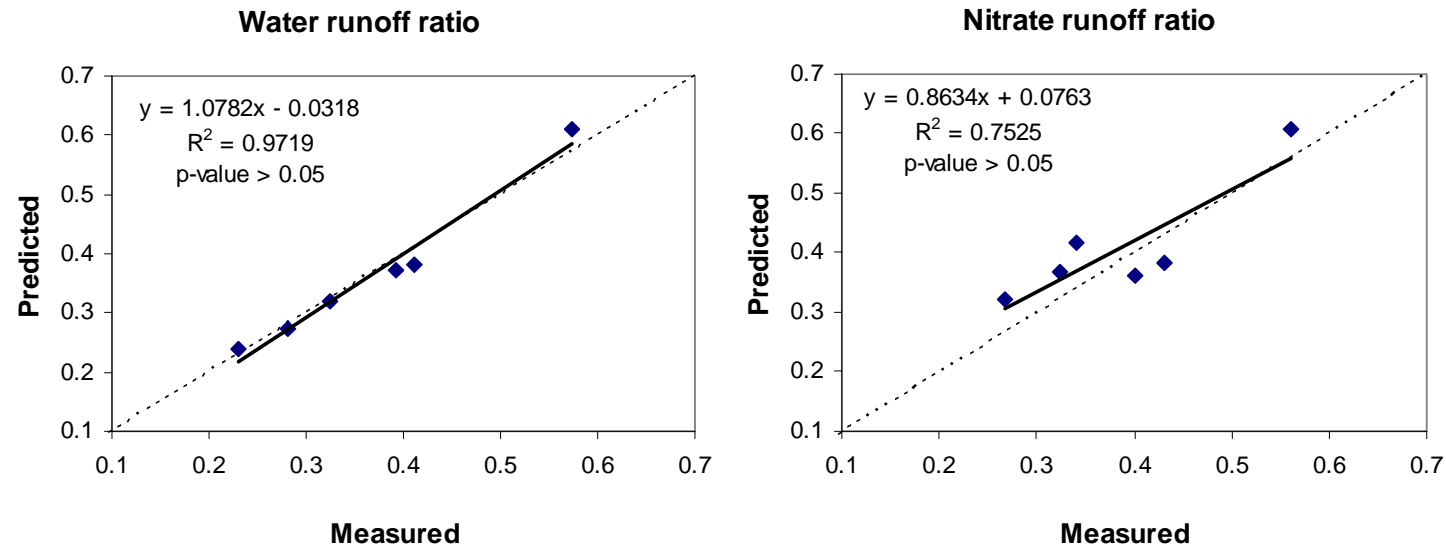
Fig. 6. Distribution uniformity of water (measured and predicted) and nitrate (predicted) in both fertigation events.
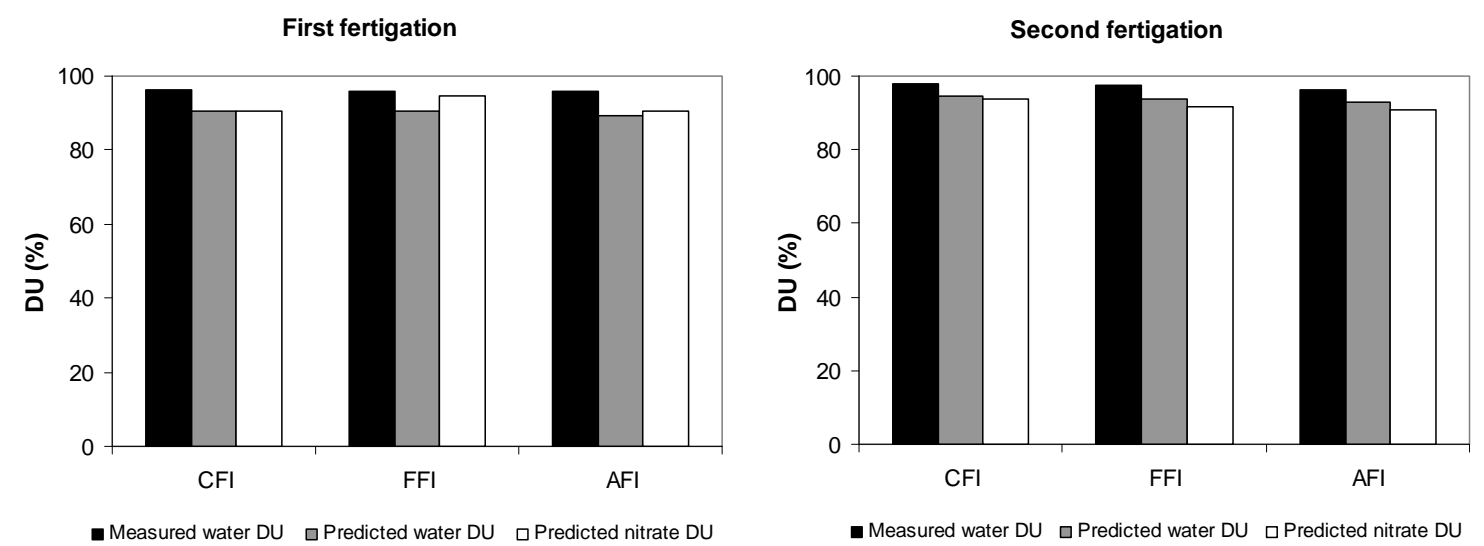
Fig. 7. Measured and predicted soil water content and nitrate concentration in the second fertigation for the three irrigation treatments.

a) Water content

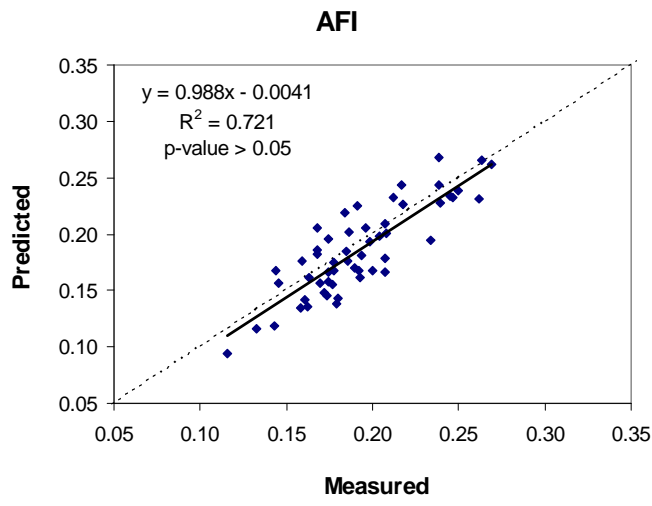

FFI

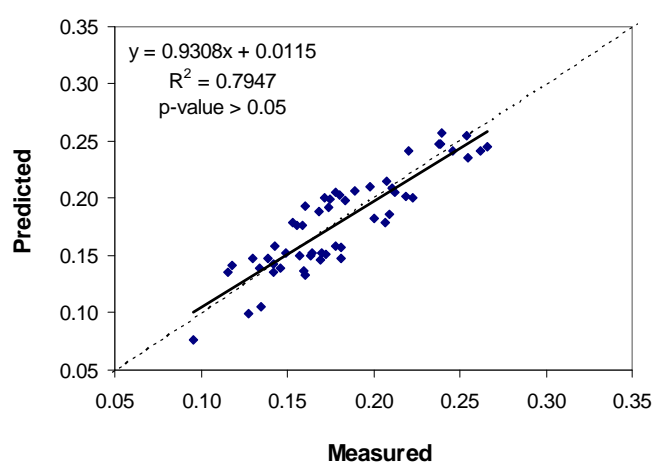

CFI

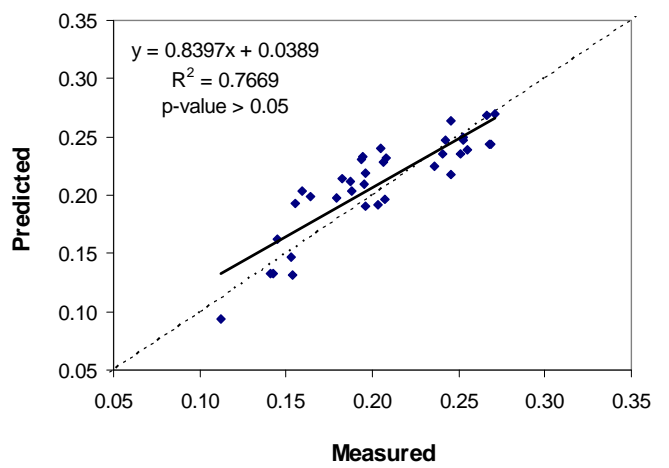

b) Nitrate concentration $\left(\mathrm{mg} / \mathrm{cm}^{3}\right)$

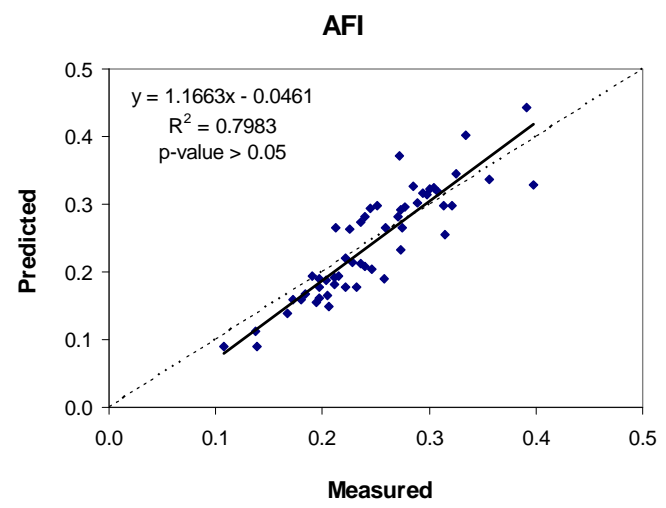

FFI

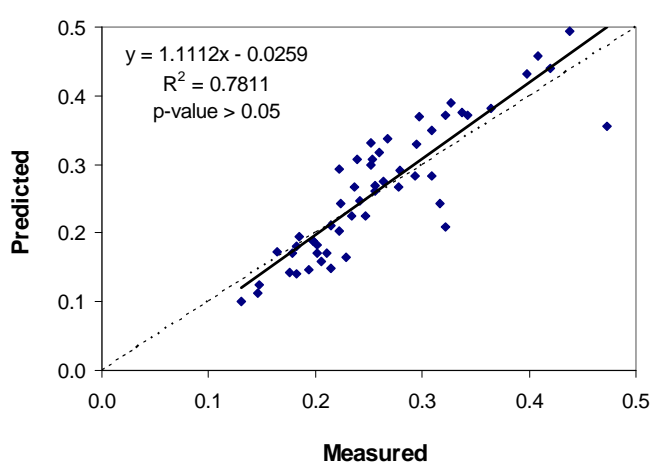

CFI

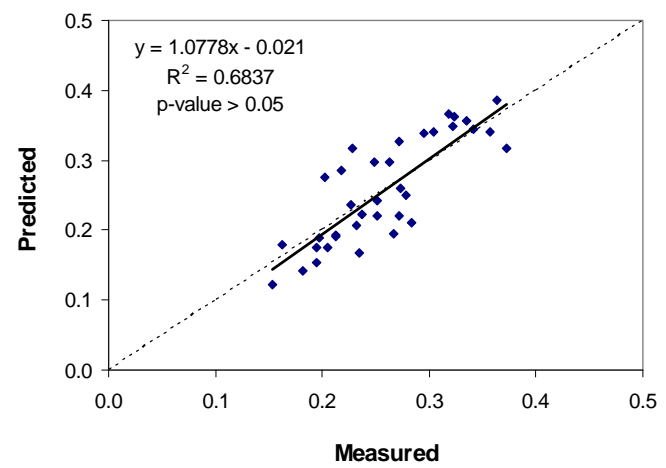


Fig. 8. Measured and predicted water content profiles below the wet and dry furrow bottoms and the furrow ridge for all irrigation treatments two days after the second fertigation event (11 August).

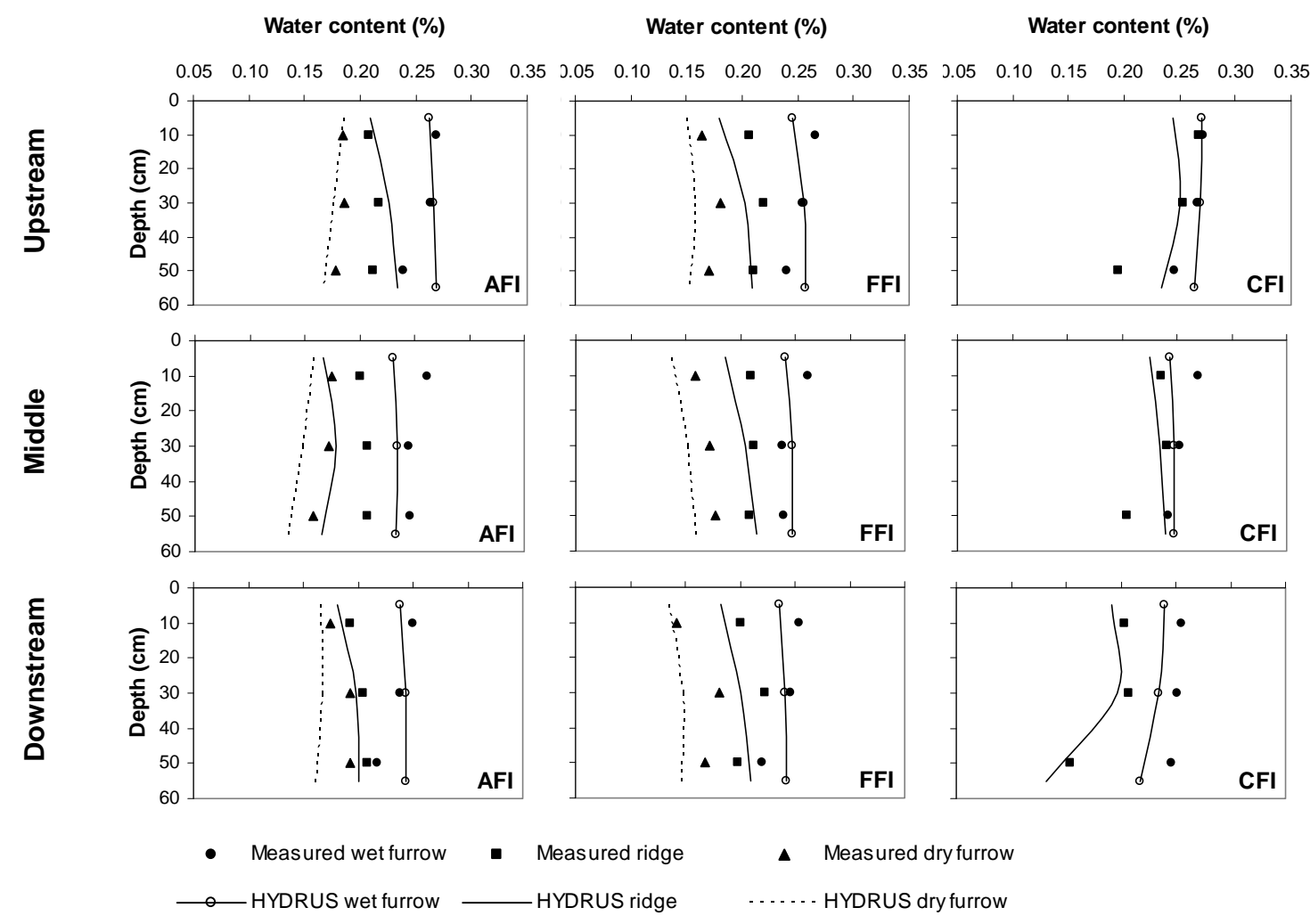


Fig. 9. Measured and predicted water content profiles below the wet and dry furrow bottoms and the furrow ridge for all irrigation treatments six days after the second fertigation event (15 August).

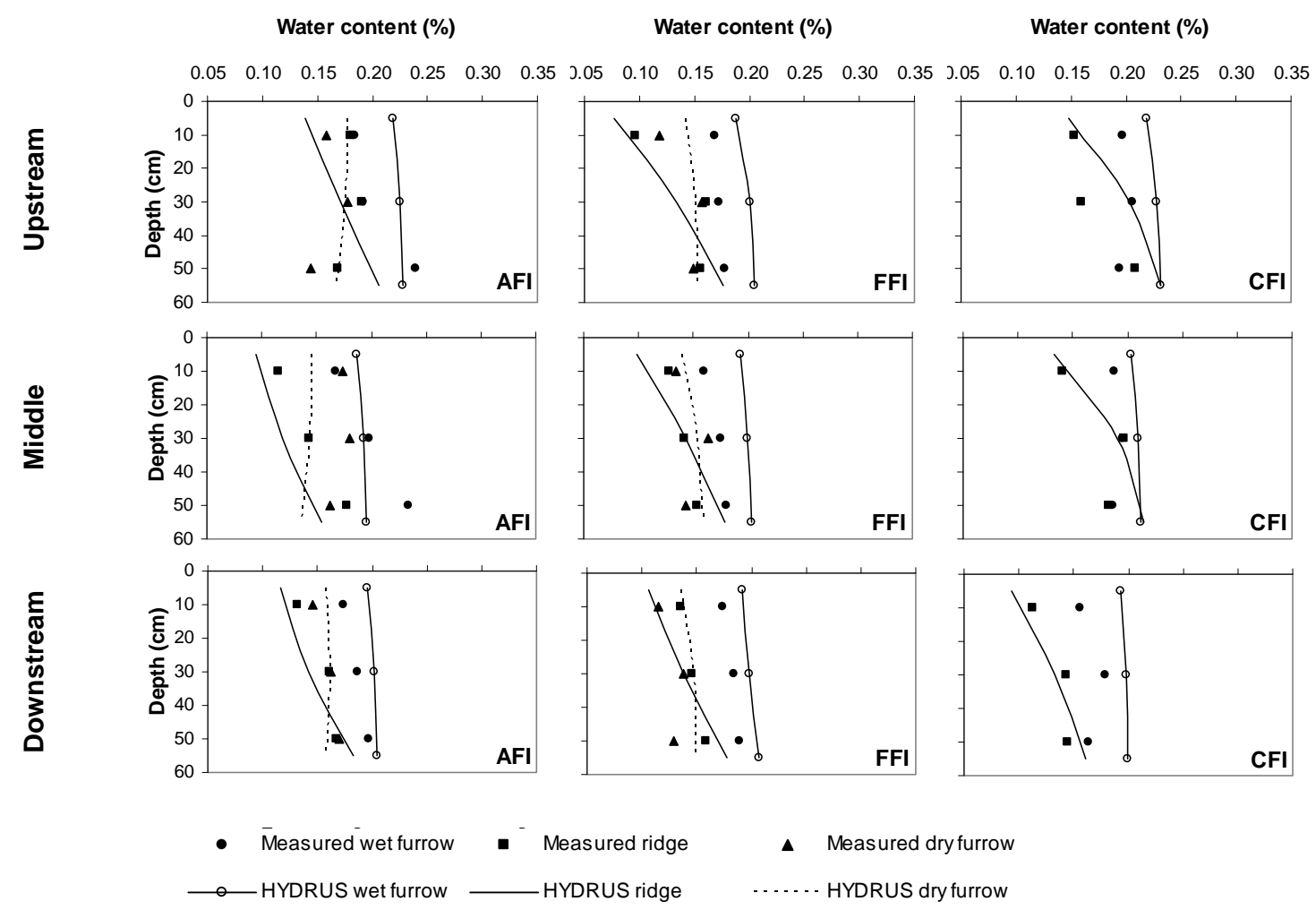


Fig. 10. Measured and predicted nitrate $\left(\mathrm{NO}_{3}{ }^{-}\right)$concentration profiles below the wet and dry furrow bottoms and the furrow ridge for all irrigation treatments two days after the second fertigation event (11 August).

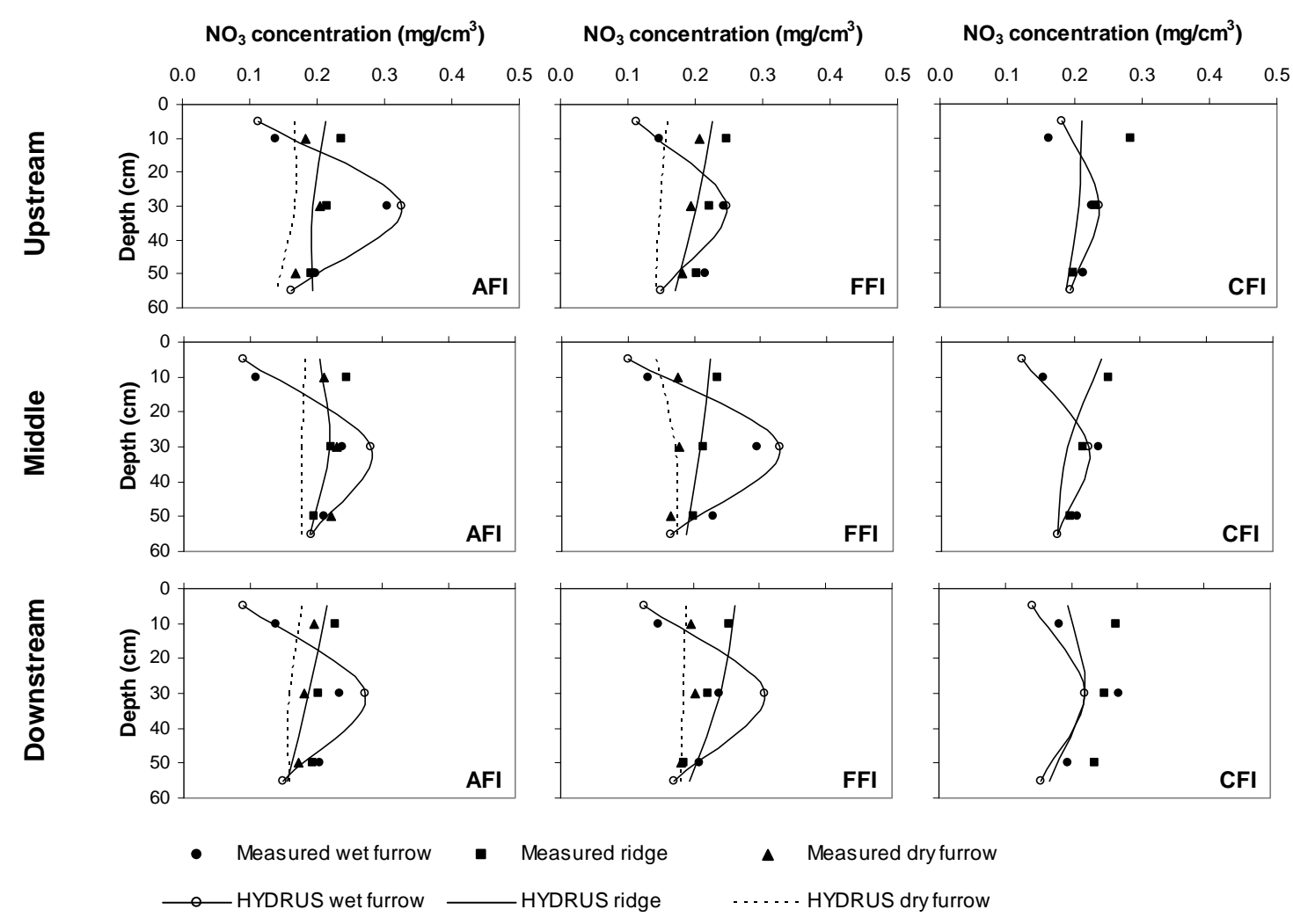


Fig. 11. Measured and predicted nitrate $\left(\mathrm{NO}_{3}{ }^{-}\right)$concentration profiles below the wet and dry furrow bottoms and the furrow ridge for all irrigation treatments six days after the second fertigation event (15 August).

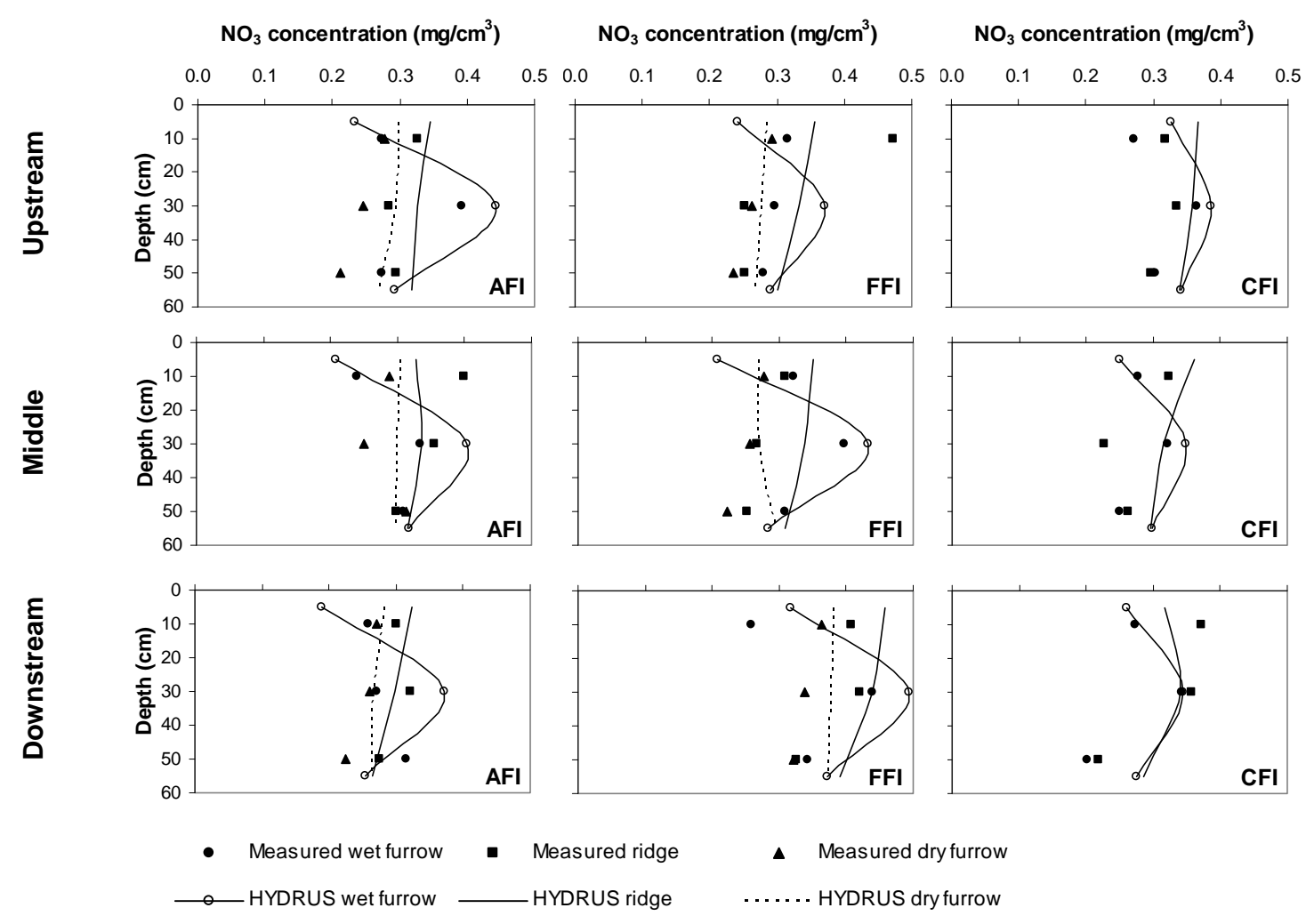

